\title{
Does The Dao Support Individual Autonomy And Human Rights? Caroline Carr
}

\begin{abstract}
The Universal Declaration of Human Rights lists what have come to be called "first" and "second" generation rights. First generation rights are civil and political; second generation rights are social, economic, and cultural. Western and Asian nations are in disagreement about whether each of these rights is universal. While Western nations strongly believe that first generation rights should be universal, many "Confucian" nations insist that second generation rights precede first generation rights. After analyzing the Confucian values in detail, I conclude that Confucianism supports both generations of rights.
\end{abstract}

\section{Introduction}

Although first generation rights are prized in Western nations, these rights and the freedoms they offer are foreign to many Asian nations, namely those that identify with Confucianism. ${ }^{1}$ China, for instance, identifies with Confucianism and denies first generations rights to its people. ${ }^{2}$ The 2014 World Report on Human Rights notes that China "places arbitrary curbs on expression, association, assembly, and religion; prohibits independent labor unions and human rights organizations; and maintains Party control over all judicial institutions." 3 Contrary to what many Confucian nations might proclaim, I argue that Confucianism actually supports first and second generations of rights. This paper explains fundamental aspects of Confucianism, then goes on to assess how they mandate both generations of rights.

\section{What is Confucianism?}

What exactly is Confucianism, and what about it seems to preclude first generation rights? Confucianism (which originated

\footnotetext{
${ }^{1}$ Francis Fukuyama, "Confucianism and Democracy," Journal of Democracy 6, no. 2 (1995): 23 ${ }^{2}$ Nathan Gardels, "Xi Launches Cultural Counter-Revolution to Restore Confucianism as China's Ideology," TheWordPost. Huffington Post, n.d. <http://www.huffingtonpost.com/ nathan-gardels/xi-jinping-confucianism_b_5897680.html>.

3 “World Report 2014: China," Human Rights Watch, http://www.hrw.org/worldreport/2014/country-chapters/china.
} 
from Confucius in $6^{\text {th }}$ century BCE) is a tradition that advocates a certain way of life marked by the achievement of virtue $(d e)$ and a proper following of the Way (Dao). ${ }^{4}$ According to the Confucian tradition, one's ability to cultivate these virtues will be imperative to one's ability to follow the Dao.

According to Herbert Fingarette, following the Dao is the ultimate goal and highest good for every Confucian. Indeed, in Confucianism: The Secular as Sacred, he explains that the "following of the Way ... is of ultimate and absolute value." ${ }^{5}$ According to Fingarette, the Dao does not offer any crossroads. Rather, it is a strict, one-way street structured by ritual propriety $(l i) .{ }^{6}$ In effect, Confucians lack a true ability to make choices when it comes to pursuing it: "either one follows the Way or one fails ... neither the doctrine nor the imagery [of the Dao] allows for choice ... there is presumed to be only one right thing to do." "Given the static nature of the Dao, Fingarette concludes that Confucians cannot have any degree of autonomy in following it.

Although I agree with Fingarette's claim that the good of every Confucian is to follow the Dao, I disagree with his view that the Dao prohibits individual autonomy entirely. From my reading of Confucianism's Four Books, I have concluded that the Dao not only has space for some degree of individual autonomy, but actually requires it. However, in order for individuals to be autonomous, they need to be granted first generation rights. Additionally, I argue that Confucianism calls for both first and second generation rights.

\section{What is the Dao?}

In order for one to be able to follow the Dao, one must first understand what exactly the Dao is. "Dao" is translated as the "Way," but can refer to "The right Way of life, the Way of governing, the ideal Way of human existence, [and] the Way of the cosmos." ${ }^{\text {It }}$ most often refers to the Way in which society is ruled and organized. ${ }^{9}$ Since this essay focuses on the rights of the individual in a Confucian society, we should discern the Dao in this latter context. Naturally,

\footnotetext{
${ }^{4}$ It is important not to confuse the Confucian Dao with the Daoist Dao, as these are two different traditions whose conceptions of the Dao differ significantly.

${ }^{5}$ Herbert Fingarette, Confucius: The Secular as Sacred (New York: Harper \& Row, 1972), 20-22.

${ }^{6}$ Ibid., 19-20.

7 Ibid., 21.

${ }^{8}$ Ibid., 19.

${ }^{9}$ Bryan W. Van Norden, The Essential Mengzi: Selected Passages with Traditional Commentary (Indianapolis: Hackett, 2009), 141.
} 
all governments are ruled and organized in order to achieve a certain goal. According to the Great Learning, the goal of every Confucian society is also "to illustrate illustrious virtue; to renovate the people; and to rest in the highest excellence." ${ }^{10}$ Ultimately, if the goal of every Confucian society is to exhibit virtue, then the Dao of a Confucian society is to illustrate virtue.

If the Dao refers to an illustration of virtue, then the aim of all Confucians should be to cultivate virtue. To be clear, the Confucian tradition has four cardinal virtues: ren, $l i, y i$, and zhi. Ren can be translated as authoritative conduct, benevolence, or humaneness, and refers to a "graded love for all human beings" that begins in the family. ${ }^{11}$ It is also the highest of all the virtues. ${ }^{12} \mathrm{Li}$ can be translated as ritual propriety; it refers to society's traditional norms, customs, and practices. Yi can be translated as "righteousness" and refers to carrying out the right action at the right time and in the right place. Finally, zhi can be translated "wisdom" or "knowledge."

According to the Mengzi, the cultivation of virtue is more than possible, because human nature is actually to become virtuous. Indeed, Mengzi says that all humans have within their hearts certain feelings: compassion, disdain, deference, and approval and disapproval. ${ }^{13}$ These feelings are important because they are the "sprouts" of virtues. Compassion is the sprout of benevolence, disdain is the sprout of righteousness, deference is the sprout of propriety, and approval and disapproval is the sprout of wisdom. ${ }^{14}$

\section{The Cultivation of Virtue and Second Generation Rights}

Although it is clear that all humans can cultivate the virtue necessary to follow the Dao, does Confucianism offer any explanation on how this is done? According to the Great Learning and the Analects, people can cultivate virtue by acquiring knowledge (zhi) and observing ritual propriety $(l i)$. In the Great Learning, Confucius says that in order for people to cultivate their persons, they must "first rectif[y] their hearts ... s[eek] to be sincere in their thoughts ... [and] extend to the utmost their knowledge. Such extension of knowledge lay in the investigation of things." 15 In order for the

\footnotetext{
${ }^{10}$ K'ung-fu Tzu, Confucius: The Great Learning, trans. James Legge (Forgotten Books, 2007), 1.

${ }^{11}$ May Sim, "Harmony and the Mean in the Nicomachean Ethics and the Zhongyong,"

Remastering Morals with Aristotle and Confucius (Cambridge University Press, 2007), 117.

${ }^{12}$ Van Norden, The Essential Mengzi, 137.

13 Ibid., 6.4.

${ }^{14}$ Ibid., 6.5.

${ }^{15} \mathrm{Tzu}$, Confucius, 1.
} 
people to cultivate the virtues for which the Dao calls, they need to extend their knowledge and investigate reality.

Although it is clear that Confucians need to acquire knowledge (zhi) and observe ritual propriety (li), does this automatically mean that they have the right to do so? In "A Confucian Approach to Human Rights," May Sim explains that the "good," the Dao, is not only an ideal for Confucians to achieve but also a right. She explains that because of Confucianism's emphasis on relationships, all people in a Confucian society are obligated to help others achieve any "Confucian goods" that may exist. ${ }^{16}$ Conversely, all people are entitled to pursue such goods. The good becomes a right to which all Confucian people are entitled. As Sim succinctly explains, since "there are basic goods and an obligation to foster them, there are 'basic' or human rights." 17

Since it has now been established that the Dao is a good which all Confucians have a right to pursue, it follows that a Confucian society has an obligation to provide its people with a right to education. In order to ensure that all people have this right, a Confucian society ought to provide them with second generation rights. This generation of rights is social, economic, and cultural in nature. It includes the right to education, housing, health, and employment. Ultimately, since a right to education is a second generation right, a granting of these rights will ensure that Confucian citizens can obtain the knowledge (zhi) necessary to cultivate virtue and follow the Dao.

In the Analects, Confucius says that observing ritual propriety allows one to achieve the highest Confucian virtue, ren: "Through self-discipline and observing ritual propriety, one becomes authoritative $[\mathrm{ren}]$ in one's conduct. Do not look at anything that violates the observance of ritual propriety; do not listen . . . do not speak ... do not do anything that violates the observance of ritual propriety." 18

Since ren is the summation of human virtue, one's ability to practice it will have the largest effect on one's ability to follow the Dao. ${ }^{19}$ In fact, the Mengzi explicitly articulates that "The Way $[\mathrm{Dao}]$ is simply to harmonize with benevolence [ren] and put it into words." 20 Therefore, in light of what Confucius said in the

\footnotetext{
${ }^{16}$ May Sim, “A Confucian Approach to Human Rights," History of Philosophy Quarterly 21, no. 4 (2004): 348.

${ }^{17}$ Ibid., 348.

${ }_{18}$ Analects, 12.1.

${ }^{19}$ Van Norden, 137.

${ }^{20}$ Mengzi, 7B16.1.
} 
Analects, a Confucian society should promote a strict adherence to ritual propriety $(l i)$. By providing second generation rights, a Confucian government can encourage the people to observe ritual propriety. Indeed, since li refers to a society's cultural practices, and second generation rights embody a society's cultural rights, then by promoting these rights a Confucian government can effectively promote ritual propriety $(l i)$.

\section{The Dao and Autonomy}

At this point, Fingarette's conclusion about the Dao is easy to understand. Fingarette views the Dao as a single path with virtually no room for any choice or freedom. This explanation seems logical because the characteristics of the Dao do seem specific. In order to follow it, one must illustrate virtue, become educated, and adhere to society's norms and customs embodied in ritual propriety (li). With such a specific prescription of the Dao, is there any room for independent choice? Despite the fact that the Dao seems fixed, the Mengzi and the Analects explain how it also requires individual autonomy.

The ability to practice the virtue $y i$ (righteousness/ appropriateness) requires one to have the freedom to make an independent choice. Since $y i$ is one of Confucianism's four cardinal virtues, an exhibition of it will be imperative to one's ability to follow the Dao.

What is it about $y i$ that demands autonomy? The appropriate (yi) action varies depending on one's social role. For instance, in the story of Feng Fu, Feng Fu is mocked for helping a mob catch a tiger because he is a distinguished official. "Feng Fu rolled up his sleeves and got out of his carriage to assist with the tiger. The mob was pleased, but those who were officials laughed at him." ${ }^{21}$ We can conclude that Feng Fu's behavior is not appropriate for his role as an official because the Mengzi uses this story to explain to Chen Zhen why his own social role does not permit him to ask for famine relief.

$Y i$ is also situational. Since no two situations are exactly alike, the appropriate action can vary by situation. For instance, imagine if the tiger were going after Feng Fu's mother. Since xiao (filial piety) is one of the most important Confucian virtues, it would be more appropriate ( $y i)$ for Feng Fu to try to save his mother by capturing the tiger than it would be for him to behave like an

\footnotetext{
${ }^{21}$ Ibid., 7B23.2.
} 
official. Therefore, in order to ensure that Confucian citizens have the ability to choose the appropriate action, they need to have the ability to think autonomously. In this hypothetical story of Feng $\mathrm{Fu}$, Feng Fu certainly needed to make an independent choice in order to perform the appropriate (yi) action of saving his mother. Since the ability to be autonomous lies in first generation rights, Confucian citizens will need first generation rights in order to exercise $y i$. Without such freedoms embodied in first generation rights, Confucian citizens may be discouraged, mocked, or even legally restrained from the ability to practice $y i$. An ability to practice $y i$ is important because it allows one to follow the Dao. Ultimately, since it is clear that first generation rights allows one to fully exercise $y i$ and follow the Dao, then a Confucian government should grant its citizens first generation of rights.

The Analects also provides evidence that the Dao requires a degree of individual autonomy. According to Confucius, the Dao can be "broadened." "It is the person who is able to broaden the way (Dao), not the way that broadens the person." 22 If it is true that people can broaden the Dao, then they need the institutional space to do so. Since the Dao refers to the way in which society is ruled and organized, citizens will only be able to broaden it if they have access to first generation rights. Only through the right to vote and the freedoms of press, speech, and assembly can Confucian citizens have the appropriate means to broaden the Way in which society is ruled and organized.

In a later passage, Confucius also explains that the Dao is able to grow from the junzi: "Exemplary persons (junzi) concentrate their efforts on the root, for the root having taken hold, the way (Dao) will grow therefrom." ${ }^{23}$ Junzi can be translated as an "exemplary" person, and refers to someone who is extremely virtuous. The possibility for the Dao to grow from the junzi is noteworthy because, even though the junzi has cultivated enough virtue to follow the Dao with precision, it is clear that he or she is still able to expand upon it. More importantly, all people have the potential to become a junzi. According to the Zhongyong:

The proper way (dao) of exemplary persons (junzi) is both broad and hidden. The dullest of ordinary men and women can know something of it, and yet even the sages (sheng-ren) in trying to penetrate its furthest limits do not know it all

\footnotetext{
${ }^{22}$ Analects, 15.29 .

${ }^{23}$ Ibid., 1.2.
} 
... The proper way of exemplary persons has its start at the simple lives of ordinary men and women, and at its furthest limits sheds light upon the entire world. ${ }^{24}$

Ultimately, since all people have the potential to become a junzi, it follows that the Dao can grow from all people.

Further supporting the idea that all people have an ability to contribute to the Dao is Analects 19.22, in which Confucius says: "The way (Dao) of Kings Wen and Wu has not collapsed utterly - it lives in the people ... Everyone has something of Wen and Wu's way in them. Who then does the Master not learn from? Again, how could there be a single constant teacher for him?"25

Despite the fact that Confucius is a sage, he is still able to learn more about the Dao from the people. This has significant implications on a Confucian government. If a Confucian society wants to better know the Dao, then it should ensure that it learns from all of its citizens. In order for a Confucian government to learn from its people, it needs to provide them with means of expression. Since first generation rights provide one with the appropriate means to express their knowledge of the Dao, a Confucian nation needs the rights to freedom of speech and assembly.

Ultimately, it is clear that all people have a potential to grasp the Dao and expand upon it. However, in order for them to do this, they need access to first generation rights. All people are entitled to the rights necessary to pursue the Dao because the Dao is the Confucian good. By granting its citizens the right to participate in politics and the rights of free speech, assembly, and press, a Confucian government is effectively granting its citizens the means necessary to achieve the good to which they are entitled.

\section{Conclusion}

All Confucian peoples are entitled to pursue the good. According to Fingarette, one can effectively choose the good by following the Dao. Although I agree that the Dao is the good, I disagree with Fingarette's view that it offers no room for individual choice. Although the Dao requires one to illustrate virtue, acquire an education, and observe ritual propriety $(l i)$, it also requires individual autonomy. The Mengzi explains that $y i$ (appropriateness or righteousness) is also required to follow the Dao. Since $y i$ varies

\footnotetext{
${ }^{24}$ Zhongyong, 12.
}

${ }^{25}$ Analects, 19.22. 
by situation, Confucian citizens need the ability to make their own choices in order to achieve this virtue. Since the ability to be autonomous lies in first generation rights, Confucian citizens need first generation rights in order to practice $y i$ and follow the Dao.

In the Analects, Confucius provides evidence that the Dao is not entirely predetermined; people, in fact, contribute to its growth. Since the Dao refers to the way in which society is ruled and organized (i.e. the way in which a government is structured), then people can only contribute to it through the political and civil rights offered by the first generation protections. By participating in politics and freely expressing oneself, one can effectively contribute to the way $(D a o)$ in which society is ruled and organized.

The Dao also supports second generation rights. Indeed, the Great Learning and the Analects explain that one can cultivate virtue by acquiring knowledge and observing ritual propriety (li). Since the right to education and other cultural rights are embodied in second generation rights, a Confucian government is obligated to provide its citizens with these as well.

Although scholars disagree on the compatibility of Confucianism and human rights, and given the significance of Confucianism in many Asian countries, hopefully this work can contribute to a shifting view of the role of first and second generation rights in Confucian societies. ${ }^{26}$

${ }^{26}$ I would like to thank the Mellon Summer Research Program (\#21100645) and Holy Cross for providing me with a grant and opportunity to conduct this research. 